\title{
An Analysis of University Teachers' Understanding about their Profession and Expectations for Their Professional Development in Pakistan
}

\author{
Abdul Hameed Lone \\ Doctoral Scholar, Department of Education, The Islamia University of Bahawalpur, Pakistan \\ Email: hameed.lone@kiu.edu.pk
}

Muhammad Shakir

Doctoral Scholar, Department of Education, The Islamia University of Bahawalpur, Pakistan.

Jam M. Zafar

Doctoral Scholar, Department of Education, The Islamia University of Bahawalpur, Pakistan.

Received: October 1, 2011 Accepted: November 2, 2011 Published: November 19, 2011

Doi:10.5296/ijld.v1i1.1100ＵRL: http://dx.doi.org/10.5296/ijld.v1i1.1100

\begin{abstract}
The main purpose of the study was to critically analyze the relevancy and effectiveness of the training contents and process of the teaching profession; to assess training needs of university and college teachers in terms of conceptualizing new meanings of education and teaching profession. The population of the study consisted of thirty teachers from different departments of The Islamia University of Bahawalpur and ten teachers from different disciplines of graduate colleges of the province. Pre-Test and Post-Test were developed as a research instrument. The researcher participated in the workshop and observed its mechanism, content, lecturers, activities, and videoconferences and exchanged views with resource persons as well as participants of the workshop. A pre-test delivered to the participants for assessing their previous knowledge about concept and meaning of teaching profession, professional ethic, teachers' personality, trends of education in $21^{\text {st }}$ century, importance of change in teachers' attitudes, different roles of a teacher, and application of new learning skills. At end of the workshop post-test was conducted to evaluate the outcomes of workshop. Researcher also observed the role of master trainer, trainee's performance, instructional material, group activities, time management, venue and refreshment. The collected data through pre-test and post test was filtered and analyzed in qualitative way. The
\end{abstract}


findings of the above analysis revealed that participants got an awareness of the impact of new approaches to teaching and learning in their institutions. However there is a considerable gap between awareness of the new trends, mastering and deeper understanding of these techniques. In the light of analysis of the research study it was found that trainees of the workshop gained enough knowledge about concept, roles, global trends in $21^{\text {st }}$ century, principles and main factors of teaching profession. In the light of findings of the study it was concluded that workshop was effective and healthy practice for the participants in the perspectives of teaching profession. It was also concluded that teachers had developed a strong awareness about their roles and commitment to adopting a very positive teaching profession. In the light of findings of the study it was recommended that such types of training work shop should be compulsory for every faculty member.

\section{Introduction}

We are currently in the midst of unprecedented change in education. Almost everything is apparently changing (Fullen.M \& Hargreaves, 1992.) and the rate of change is accelerating. The role of educational leaders, mangers and teachers will all be different in the future from what they been in the past and everything is happening at a very fast rate, which leaves us little time to become acclimatized to new ways of looking things.

In addition to change coming at us from government, we also have the changes resulting from the rapid development of knowledge, which is making existing knowledge out of date very quickly. A great deal that we are currently teaching in universities and colleges, if not already out date, will become so in the very near future.

The speed of change and the explosion of knowledge are requiring people to learn afresh at intervals throughout their personal and professional lives. This has important implications for the role of the universities and colleges, which are no longer, that pf providing a package of knowledge and skills to serve a person for life. Now that it is possible to have vast stores of knowledge available at the touch of a key, the emphasis in training of higher education teachers needs to be on the process of learning. Today's young people need a level of knowledge, which enables them to fit new learning into a information so that they can apply it in new situations. This places an emphasis the application of what's learned. Most of the developments we have seen recently, such as HEC initiatives and role in teacher training reflecting this.

Teachers must develop and capitalize on those skills that are not easily replaced by the microelectronic devices, human and personal skills of communications, motivation and counseling, design skills for producing computer based software and evaluation and research skills to assess the impact of the media and methods. These are different from the skills currently possessed and valued by the teaching profession, and they may be distributed differently among the population from which it draws. Education in the future will demand a highly skilled teaching profession but of a different character. To cater with emerging changes 
and challenges (Fullan, 2003) emphasis that teacher education still has the honor of being simultaneously the worst problem and the best solution in education.

Higher Education Commission (HEC) Pakistan has improved the whole process of teacher training in recent years. One landmark of change was the commencement of university based professional training for university and college teachers, which has a main purpose to:

- Promote systematic and purposeful implementation of in-service training.

- Promote the professional development of university and college teachers to encourage more effective management of teaching force and to

- Encourage training in selected areas, which are to be accorded appropriately.

\section{Objectives of the Analysis}

The objectives of this study were to;

1. Critically analyze the relevancy and effectiveness of the training contents and process of the module -1 'Teaching Profession'

2. Assessing training needs of university and college teachers in terms of conceptualizing new meanings of education and teaching profession, role of teacher and teachers' personality for effective teaching.

3. Propose recommendations for improvement in the process of university higher education teacher training programs.

\section{Expectations of the participants}

The Trainee group was composed of a much diversified academic and institutional background. The faculty members from social sciences, library, supports and basic sciences departments of the Islamia University of Bahawalpur were sitting together with the college teaching faculty of different subjects. The facilitators of the training program were expected to introduce a balanced input and suggest its applications to gratify all varied needs of the trainees.

The purpose of eliciting expectations of the training participants' was to explore their motivation and interests to learn develop their professional skills from this particular module 'Teaching Profession'. These findings would help the facilitators to enfold the relevant feedback from them and to bridge up the gaps in the contents and pedagogy, which have already been planned in the module to teach during this training program, and what the trainee participants were expecting to learn

The teaching profession was the first module of the program; so the participants had not a focused idea of what would have been included in the module. General concepts about good teaching and expectations to learn them were floating among the participants. They were of the 
idea that this particular module will help them understand the new methods of teaching and will improve their existing lecture techniques in the classroom. Majority of them were of the opinion that they will be able to better articulate with the use of modern technology in their classroom teaching as according them this is a great demand of the modern teaching methods. Some of the participants were expecting that in the current era of teaching job, a teacher has to play variety of roles in the university and colleges. In this regard they were expecting that this module will help improve their effective role of undertaking versatility of responsibilities. Few of them were expecting to learn about the use of computer and techniques of time management with an understanding that these are very important factors for teacher to cope with the needs of $21^{\text {st }}$ century.

\section{Analysis of Pre and Post-Training Concepts}

All training participant filled an investigative questionnaire before and after the module delivery to analyze the level of changes in their understanding of the following training concepts'
i. $\quad$ Meaning of Education
ii. Professional ethic
iii. Teachers personality
iv. Trends of Education in $21^{\text {st }}$ century
v. Importance of change in teachers attitudes
vi. Different roles of a teacher
vii. Application of new learning skills

\subsection{Meaning of Education}

Before the inception of the module, 'teaching profession' majority of the participants had very stereotyped concepts of the meaning of education. They shared their understanding that education is responsible to make them good citizens and fruitful community members of the society. Some participants had the idea that education makes a personality into a complete human being. Few participants shared that education is the process of teaching and learning and sharing of knowledge, which enable them to solve their problems and further helpful in using modern technology in their lives.

In the end of the module maximum of the participants have seemed modified their understanding about the meaning of education to extend that, education is a process of acquiring knowledge and information through a process and transfer it to the students by teaching and learning procedures in the classrooms at the universities and colleges. This seems the effect of introduced meaning of the concept during the workshop, which has changed the trainee's concept of education, now they were focusing upon the knowledge imparting processes in the classroom by teachers and the skills required to transfer it to their students by the effective methods. 


\subsection{Professional Ethics}

At the beginning of the module participants described the professional ethic; as it is important skill for them to observe regularity and punctuality in their jobs. It also helps to create a healthy environment and positive attitude in their duties.

During the workshop the facilitator has introduced variety of activities and created discussions to make them better understand that; what the professional ethic is all about, and how it is important to practice in our personal and professional life. The resource person discussed that ethic is not limited to the environment of an institution or the commitment of teachers to their jobs, but it is more than that, it largely surrounds the life standards, set of professional values and social skills that enables the teachers to develop effective professional behaviors during their teaching practices. These are basically life values including, care, trust, respect and integrity needed to for professionals to practice in their daily life personally and professionally to avoid and resolve conflicts.

By the conclusion of the module a range of new meanings and improvements were apparently occurred in their concepts. Now they were of the impression that professional ethic is very important aspect for teachers to develop and practice acceptable norms and values in their behaviors and practices so that diverse cultural, social and moral values can be respected and accommodated during the discussions and sharing of ideas about a particular concept in classrooms and outside the classroom. Few participants were very confident that good behavior and values are not only essential to show respect for others vis-à-vis earn respect and acceptance from other people. They feel that professional ethic is an ingredient for a person to acclimatized him/her with in pluralistic culture of the society.

The findings of post-module concepts of the participants reflects an apparent change in the their motivation towards adapting acceptable values and standards in their professional lives. It further depicts their understanding and realization of the importance of professional ethic that they are carrying with them to their professional responsibilities and practices.

\subsection{Teachers' Personality and Attitude}

Teacher's overt appearance and behavior always play a greater impact towards the acquiring of concepts and knowledge that they are presenting in the classroom teaching to their students. Before the initiation of the module, participants have a vague idea of the role of teacher's personality. They were mixing up obvious personality aspects of a teacher with the teaching skills, classroom environment and professional ethics. They see personality limited to creating conducive environment and punctuality in their jobs and professions. Moreover they relate the teachers' personality into the teaching manners and command on subject matter of the teacher while teaching in the university or in colleges.

During the learning process of the concept participants were introduced with a list of personal traits and personality characters. They worked in groups and peers and developed a long list of new personality traits, which are very essential for the teachers to inspire their students towards their learning activities. 
When asked the same question at the end of the module, they came up reasonably with a changed and new understanding of the concept teachers' personality and its' impact upon learning behaviors by their students in classes. Now they sensitized with the idea that teacher personality and personal traits, behavior, respectable appearance and balanced attitude towards their students play a vital role. Students' unusually want see their teachers as role models for their own personality and growth in their future. The inspiration that helps students to be like their teacher in their future role largely depends upon on the level of charisma that a teacher displays in his/her professional and personally practices.

The data shows that the participants have significantly sensed the concept of 'seeing is believing' plays a vital role, it is always applicable for the influencing others through actions and personal appearance. In teaching profession personality appearance, behaviors and unbiased repertoire of practices is very important for them to influence their students to become more caring and developed citizens of the society.

\subsection{Trends of education in $21^{\text {st }}$ century}

In response to the query, how they understand the trends of $21^{\text {st }}$ century? Largely the participants have the concept that $21^{\text {st }}$ century education is all about the learner centered teaching process. They consider it a challenge for educational leaders and management to cope with the availability of modern teaching aids and the training for all teachers to be able to use them effectively. They feel that new electronic and computer technology is inevitable for teachers to learn about it, and apply efficiently in their teaching and learning process in the classrooms. They also highlighted the issue that teaching must be acknowledged as a very important profession not as just a job in the $21^{\text {st }}$ century. They further elaborated the inclusion of research and practical implications of the concepts are the basic needs of the new century requirements. For that some of them suggested to enable the teachers to be innovative and develop their communication skills. They have suggested that a teacher now needed to learn more then content and pedagogical knowledge because he/she has to play a more dynamic of role in universities and colleges.

The participants strengthened their concepts almost all the aforesaid responses at the end of the module with a strong emphasis upon the practical application of the new educational skills in our professional, social and daily life. Some of them came up with the notion that the old century was theoretical in understanding the text concepts. Now the century have evolved into a very practical manner students are expected to develop practical skills of knowledge to improve our daily life standard. They were suggesting that creativity and use of modern technology is very essential rather unavoidable to be focused in our institutions. The teachers who are not aware of these modern trends must make their best endeavors to accomplish these new trends in their professional lives.

Apparently the deliberations of new trends are very generic in nature, all teachers and students seems very concerned to cope with the demands of $21^{\text {st }}$ century which is a strong positive aspect of the training program. 


\subsection{Different roles of a teacher}

In response to their prior concepts of versatility and playing different roles in the department or in the institutions; majority of the training participants were holding the concept that, strong command on subject matter knowledge and proper research skills are the most important role that a teacher has to understand to be an effective university teacher. Few even did not respond the question and a small number the participants have the notion that communication skills, administrative skills and good teamwork is another important role that a teacher need to learn and play in their professional life.

During the deliberation process of the module particularly upon the concept of 'teachers roles and responsibilities' the facilitator engaged the participants in hands on and minds on activities to develop and discuss a list of responsibilities apart from teaching that almost every teachers at higher education level is engaged in running the departments or colleges effectively. The summary of module contents were also distributed to each participant to further enriches their comprehension about the discussion that they had during the module.

In the end of the module they again came up with the same perceptions that they have learnt during module, especially to become an effective teacher. Training participants have strongly put their stances that for effective teaching. Teachers are required to improve their communication skills, teamwork and use of educational technology in their classes.

The data reflects that there was a strong need to sensitize the participants to aware them with concepts of management and administrative rather, leadership role to be understood during the learning activities. These skills would hopefully enable them to create a thrust and enthusiasm to become a more dynamic personality and professional in their institution.

\subsection{Learning application}

A crucial question was asked at the end of the module that how would they apply their new learning in their professional practice? Apparently a range of very imperative ideas evolved in the responses. They all seemed very confident and enthusiastic to improve their lectures by incorporating creative group work and discussion during the lectures. The data reveals that participants are very eager to use modern electronic technology during teaching in the classroom. They showed a huge interest and motivation to display a very friendly attitude and take care of social and moral values to their students inside and outside classroom activities. The data further depicts that they also are committed to involve themselves and their students in creative research activities, which they feel has a pivotal role university teaching profession.

The data further elaborates that majority of the participants are very keen to apply the new learning into their professional practice as teachers of new generation. They are promising by themselves that from now to onward their teaching will revolve around the personality and 
character building of their students. They will try to modify the behaviors and attitudes of their students with imparting the content knowledge, as according to them, prior to this workshop was not on the focus of their teaching. They were merely transferring the content knowledge and had the feeling that this is the only responsibility of a teacher. Very few responses are not hopeful in applying the new skills in their future teaching practice; they were making excuses of not having the relevant resources and equipments in their institutions to apply the new learning in their practices.

In conclusion the data reveals that teachers have developed a strong awareness about their roles and commitment to adopting a very positive professional. Conceptually they have taken the responsibility of preparing good teaching methods by using the technology and will respect the individual learning needs and diversity of culture and background of their students. This shows a great level of effect and success of the training workshop.

\section{Challenges faced}

The group of divers background teachers while enthusiastic about the positive impact of new teaching strategies learnt from the program seemed very reluctant during in-formal tea break talks and corridor gossips. They were complaining on their existing strong traditional infrastructure of the department/institution and workload, which is not according to them helpful and conducive to apply what they have learnt in the workshop. They shared their concerns of not having supportive heads and seniors in their subject area to encourage and facilitate them to be innovative and creative in their teaching. What emerged strongly from these talks was the depth to which the conservative and traditional notions of leadership approach and to certain contextual realities, which discourages the young faculty to apply the new skills in their profession.

The college teachers were seemingly more hesitant. They were talking about the role their annual system of assessment and external factors of examination, which will not encourage them to focuses upon the students' behaviors rather that focusing only on the textbook crammed knowledge and students memory. According to them semester system in universities is more feasible to apply these newly learned ideas because the teachers in university are empowered to conduct and assess their students learning achievements.

Ignorance of time management was an important factor observed during this module. Majority of the course participants did not bother the importance of regularity and punctuality during the workshop in different sessions. Some participants were used to come late in the beginning of the session and some are used to disappear after tea breaks was a major concern for the facilitator. They were making excuses, as they are engaged with other routine activities in their departments concurrent with the workshop.

Preparation and distribution of an accumulative training program schedule, day to day work plans, identification of resource persons and handouts for each topic to reinforce their 
classroom discussions are a key factor to keep participants vigilant and accountable for their learning during and after the workshop. Participants were found very inquisitive about the handouts after the input by facilitator and presentations. By the end of each day they constantly showed their curiosity to know, who will be the resource person for next session and what would be the topic to ponder upon.

\section{Conclusion}

The findings of the above analysis reveal that participants got an awareness of the impact of new approaches to teaching and learning in their institutions. However there is a considerable gap between awareness of the new trends and mastering and deeper understanding of these techniques. Teachers understanding about the new trends are at the level of superficiality. Conceptualization of the new educational trends and methods to be the most needed focus of professional development endeavors. Teachers need to acquire the skills and knowledge of the techniques, which make the student, centered approach meaningful and productive. Participants' awareness and wish to apply the new teaching approaches is a positive sign, and could also imply at the beginning when they go back to their departments. However, lack of support to understand and move into right direction may have an adverse effect on their motivation and attitudes towards the new trends and they may revert to their prior teaching.

Teachers' beliefs are largely shaped by their experiences. Decline in the recognition and respect for teachers by the community and the authorities in the department or institution seems have tremendous impact on teachers' work. Their emotions and hopes are negatively affected. This is probably the main reason that participant are reluctant to use the new trends in their practices.

The strongly positive indicators of faculty development program for university and college teachers who participated in the module lead me to believe that professional development programs such as HEC faculty development program should be an ongoing partnership between HEC and University education department in foreseeable future. It is also felt by the observers that a large number and variety of concepts, topics, issues, teaching and learning strategies introduced during the program was a useful exercise for both facilitator and participants. However it is also felt on occasions the relatively large curriculum content put added pressure on facilitator to effectively share the course with the participants as well as for participants to understand and internalize the course contents within the stipulated time frames. In this respect a more selective approach to including strategies and skills in the curriculum of the module would enable all concerned to have a more in depth learning experiences rather than 'scratching the surface' as sometimes seemed to be the case. 


\section{References}

Kauchak, D., \& Eggen, P. (2005). Introduction to teaching: Becoming a professional.

Dewey, J. (1916). Democracy and education. New York: Macmillan.

Farrell, T.S.C. (2004). Reflective practice in action: 80 reflection breaks for busy teachers. Thousand Oaks, CA: Corwin Press.

Pedro, J. (2006). Taking reflection into the real world of teaching. Kappa Delta Pi Record, 42(3), 129-133.

Schn, D.A. (1996). Educating the reflective practitioner: Toward a new design for teaching and learning in the professions. San Francisco: Jossey-Bass.

Vygotsky, L. (1978). Mind in society: The development of higher psychological processes. Cambridge, MA: Harvard University Press.

Fullan M., \& Hargreaves, A. (Eds.). (1992). Teacher development and educational change. The FalmerPress, New York.

Cochran-Smith, M. (2004). Taking stock in 2004: Teacher education in dangerous times. Journal ofTeacher Education, 55(1), 3-7.

Laitsch, D., Heilman, E., \& Shaker, P. (2002). Teacher Education, pro-market policy and advocacy research. Teaching Education, 13(3), 251-271.

Bellah, R.N., Madsen, R., Sullivan, W.M. Swidler, A, \& Tipton, S.M. (1985). Habits of the heart: Individualism and commitment in American life. New York: Harper \& Row.

Covey, S.R. (1989). The seven habits of highly effective people: Powerful lessons for personal change.New York: Simon \& Schuster.

Friedman, T. L. (2005). The world is flat. New York: Farrar, Straus, and Giroux.

Rogers, E.M. (2003). Diffusion of innovations (5th ed.). New York: Free Press. 